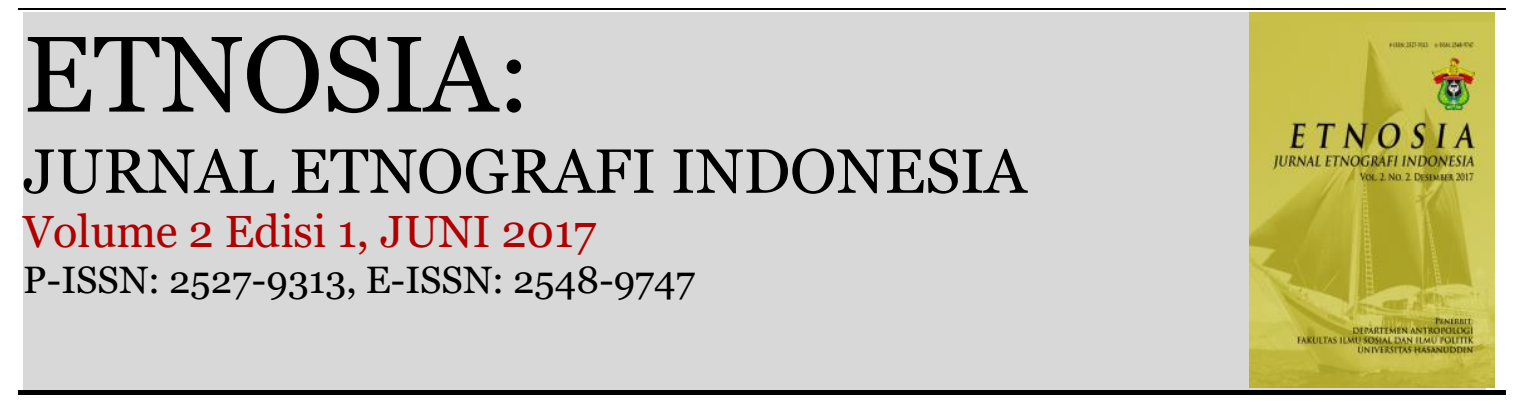

\title{
Kekerasan Kolektif di Perkotaan: Konstruksi dan Representasi Maskulinitas dalam Budaya Masyarakat Makassar
}

\section{Syaiful}

Jurusan Sejarah dan Kebudayaan Islam, Fakultas Adab \& Humaniora, Universitas Islam Negeri Makassar.E-mail: syaifulsimollah@yahoo.com

\begin{tabular}{|c|c|}
\hline ARTICLE INFO & ABSTRACT \\
\hline $\begin{array}{l}\text { How to cite: } \\
\text { Syaiful. M. (2017). } \\
\text { Kekerasan Kolektif di } \\
\text { Perkotaan: Konstruksi dan } \\
\text { Representasi Maskulinitas } \\
\text { dalam Budaya Masyarakat } \\
\text { Makassar. Etnosia: Jurnal } \\
\text { Etnografi Indonesia. } \\
\text { 2(1):95-116. }\end{array}$ & $\begin{array}{l}\text { The occurrence of violence in South Sulawesi whereever they are, they } \\
\text { are usually identified as violence that happen in Makassar. This is due } \\
\text { to the fact the frequent of violence happen in Makassar than in other } \\
\text { cities in Indonesia. This article aims to explore collective violence in } \\
\text { two adjoining locations in Makassar, yakni Pampang dan Sukaria and } \\
\text { how this is related to masculinity. The pattern of collective violence } \\
\text { between people in both areas based on classification and motivesof } \\
\text { conflict between groups. The motive of collective violence, namely } \\
\text { yakni seizure of land, this then develop mass coordination established } \\
\text { through the process of patronage relations and the formation of strong } \\
\text { lokal men. This then lead to establishment of routine violence which } \\
\text { hands in hand in hand with siri' na pacce. The construction of } \\
\text { masculinity from male perspective that women are obliged to maintain } \\
\text { such values through violent ways. Parenting pattern tends to be } \\
\text { permissive towards violence. Such violence is common among male } \\
\text { members of society. This violence has become an expression of } \\
\text { masculinity. Masculinity is symbolised through four aspects: badik, } \\
\text { bow arrow, tatto' dan ballo (a local drink). Thus, one who can } \\
\text { performs these aspects will be considered as rewa. }\end{array}$ \\
\hline
\end{tabular}

Copyright @ 2017 ETNOSIA. All rights reserved.

\section{Pendahuluan}

Kekerasan di Kota Makassar cenderung memiliki frekuensi dan tingkat kekerasan kolektif yang relatif lebih tinggi dibandingkan dengan daerah lain yang ada di Indonesia. Data yang tersaji, secara umum dari semua jenis konflik kekerasan yang melibatkan kolektif, pada tahun 2008 di negeri ini telah terjadi sebanyak 1136 kasus kekerasan yang sempat terekam. Daerah Sulawesi Selatan berada di peringkat kedua setelah kabupaten Jawa Barat yang hanya berselisih satu kasus saja. Dari 124 jumlah kasus kekerasan yang terjadi di Sulawesi 
Selatan pada tahun 2008 itu, ternyata diramaikan jumlahnya oleh kasus tawuran antar kelompok yang begitu banyak melebihi konfik kekerasan agama, politik, pengeroyokan hingga penghakiman kolektif. Dari data tersebut, 85\% dari semua kasus kekerasan yang ada di Sulawesi Selatan terjadi di Kota Makassar sebagai Ibukota provinsi (Manji, 2011:4-5).

Penelitian-penelitian terdahulu terkait kekerasan di Kota Makassar dalam sepuluh tahun terakhir cenderung difokuskan pada kekerasan mahasiswa (ASKI 2013; Sahab dan Muzaqqi 2012; Hasse 2012), masing-masing dengan fokus yang berbeda. ASKI (2013) menggunakan pendekatan komparatif di tiga kota besar di Indonesia (Jakarta, Yogyakarta dan Makasar) dengan berfokus pada aspek reproduksi kekerasan di kalangan pemuda. Temuannya menunjukkan bahwa fenomena kekerasan pemuda, dalam hal ini mahasiswa di tiga kota memiliki karakteristik yang sama. Khusus di Kota Makasar, aktor utama kekerasan pemuda didominasi oleh mahasiswa, sehingga dinilai bahwa wajah kekerasan pemuda di kota Makasar lebih banyak diwarnai oleh kelompok sosial ini. Sahab dan Muzaqqi (2012) lebih menitikberatkan pada kekerasan kolektif yang terjadi di kalangan mahasiswa di Kota Makassar. Hasil penelitiannya menunjukkan bahwa kekerasan massa yang dilakukan oleh mahasiswa Makassar cenderung dikarenakan oleh konstruksi budaya yang dimiliki oleh masyarakat bugis-makassar. Sementara Hasse (2012) berfokus pada aspek anarkisme demonstrasi mahasiswa dengan studi kasus Universitas Islam Negeri Alauddin Makassar. Studi Manji (2011) menitikberatkan peran Pemerintah Kota terhadap perkelahian antar kelompok Makassar ketimbang kelompok warga itu sendiri. Manji mengemukakan bahwa sesungguhnya dibalik berulangnya tindak kekerasan perkelahian massa di Kota Makassar tidak terlepas dari peran Pemerintah Kota Makassar yang belum menemukan solusi efektif dalam menangani perkelahian antarkelompok tersebut.

Jika dibandingkan dengan kota-kota lain di Indonesia, frekuensi kekerasan di Kota Makassar yang jauh lebih tinggi. Ini tidak terlepas dari konsep siri' (harga diri/malu) dan pacce (solidaritas sosial). Kekerasan merupakan bentuk prilaku rewa (berani) sebagai ekspresi maskulinitas mereka. Dalam konteks tersebut, kekerasan kolektif dijadikan sebagai 'ruang' untuk menunjukkan eksistensi diri sebagai orang rewa dan identitas kolektif. Momen perkelahian antar kelompok diciptakan menjadi arena pertarungan citra eksistensial dan bargaining position di antara kelompok pemuda dalam pembuktian 'kelaki-lakian' dan 'ke- rewaan' diantara mereka. 
Maskulinitas sebagai sebuah konsep sosio-antropologis seringkali diidentikkan dengan sifat jantan, agresif dan berani. Dalam kebudayaan Makassar, maskulinitas berarti memiliki nyali yang besar. Meskipun setiap kebudayaan memiliki pemaknaan maskulinitasnya sendiri-sendiri, akan tetapi terdapat suatu kesamaan yang sulit dinafikan, yakni menjadi maskulin itu artinya menjadi laki-laki yang sesungguhnya. Disinilah letak keterkaitan antara maskulinitas dan kekerasan, sebab seringkali maskulinitas dijadikan alasan pembenaran bagi sebagian laki-laki dalam masyarakat atas aksi-aksi agresif dan sikap berani membela apa yang diyakini benar dengan menggunakan segala cara, termasuk kekerasan. Oleh karena itu, menurut peneliti bahwa kekerasan kolektif yang terjadi di Kota Makassar dianggap berkaitan langsung dengan maskulinitas. Hal ini sejalan dengan apa yang dikemukakan oleh Darwin (1999:3-4) bahwa kekerasan secara tradisional juga merupakan stereotip lakilaki. Kata masculine sendiri dekat dengan kata mascle (otot) yang dapat segera diasosiasikan dengan kekuatan, keperkasaan, kepahlawanan, dan kekerasan. Artikel ini bertujuan untuk mengeksplorasi bagaimana kekerasan kolektif yang terjadi di Makassar dalam kaitan dengan maskulinitas.

\section{Metode Penelitian}

Penelitian dilakukan di dua wilayah, Pampang dan Sukaria, di Kota Makassar. Kedua wilayah ini merupakan wilayah yang sama-sama berada pada satu kecamatan, yakni Kecamatan Panakkukang. Pampang merupakan nama kelurahan dari 11 kelurahan yang berada di Kecamatan Panakkukang. Sukaria merupakan nama jalan yang berlokasi di wilayah Kelurahan Tamamaung. Kelurahan Tamamaung sendiri juga merupakan bagian dari Kecamatan Panakkukang. Kelurahan Tamamaung terletak bersebelahan dengan Kelurahan Pampang yang hanya dipisahkan oleh jalan raya kota.

Informan dalam penelitian ini berjumlah sepuluh orang yang bervariasi mulai dari anak muda, ibu rumah tangga, pekerja kantoran, satuan keamanan kampus, serta aparat pemerintah kelurahan yang berdomisili di wilayah Pampang dan Sukaria. Sebagaimana dijabarkan secara detail dalam Tabel informan berikut ini:

Tabel 1. Informan Penelitian

\begin{tabular}{llccl}
\hline No. & Nama/Inisial & Umur & Gender & \multicolumn{1}{c}{ Pekerjaan } \\
\hline 1. & Danger & 21 & Laki-laki & Tukang Parkir \\
\hline 2 & Burhan & 25 & Laki-laki & Buruh Bangunan \\
\hline 3. & Jack & 27 & Laki-laki & Kuli Bangunan \\
\hline 4. & Adnan & 33 & Laki-laki & Serabutan \\
\hline 5. & Herman & 38 & Laki-laki & PNS \\
\hline
\end{tabular}




\begin{tabular}{lllll}
\hline 6. & Anna & 40 & Perempuan & IRT \\
\hline 7. & Acox & 42 & Laki-laki & Satpam \\
\hline 8. & Usop & 43 & Laki-laki & Buruh Bangunan \\
\hline 9. & Samson & 55 & Laki-laki & Wiraswasta \\
\hline 10. & Sumanto & 60 & Laki-laki & Ketua RW \\
\hline
\end{tabular}

Teknik pengumpulan data melalui observasi dan wawancara mendalam (indepth interview). Pengamatan dilakukan terhadap individu sehari-hari dan dalam perkelahian kelompok dalam momen perkelahian antarkelompok.

Analisis data dilakukan melalui tiga alur, yakni: (1) reduksi data, (2) kategori data berdasarkan tema-tema yang muncul, seperti awal konflik, motif kekerasan, pola kekerasan, maskulinitas, dan kekerasan kolektif. Setelah melakukan kategorisasi, maka dilakukan penyusunan data secara sistematis berdasarkan tema-tema tersebut.

Izin penelitian diperoleh melalui Pemerintah Kota Makassar. Sebelum wawancara dilakukan, informan diminta kesediaannya untuk diwawancarai (informed consent) dan direkam. Semua nama yang digunakan adalah nama samaran (pseudonym) dan semua informasi dijaga kerahasiaannya (confidential).

\section{Motif dan Pola Kekerasan Kolektif}

Motif dan pola kekerasan kolektif adalah dua hal yang saling berkaitan atas terjadinya berbagai kekerasan. Sessi ini akan diawali dengan mendiskusikan tentang bagaimana motif kekerasan kolektif yang terjadi. Ini kemudian diikuti dengan penjelasan tentang bagaimana pola kekerasan kolektif yang terjadi antar warga Pampang dan Sukaria.

\subsection{Motif Kekerasan Kolektif}

Motif dalam pengertian umum adalah dorongan yang menggerakkan seseorang bertingkah laku dikarenakan adanya kebutuhan-kebutuhan yang ingin dipenuhi oleh manusia. Motif juga seringkali dianggap sebagai daya penggerak dari dalam dan di dalam subjek untuk melakukan aktivitas-aktivitas tertentu demi mencapai suatu tujuan (Sardiman 2007:73). Dalam konteks kekerasan, motif bisa diartikan sebagai latar belakang yang menjadi alasan seseorang dalam berbuat kekerasan.

Untuk memahami lebih jauh terkait peristiwa dan momen kekerasan yang ada, menjadi penting untuk melihat proses terjadinya sebuah konflik dan motif- 
motif yang melatarbelakangi kekerasan ini dapat terjadi. Proses terjadinya konflik antara kelompok Pampang dan Sukaria dalam menganalisis faktor pemicu mengapa kekerasan kolektif yang terjadi tersebut bisa berlangsung secara terus-menerus dari generasi ke generasi. Padahal, terkadang persoalan yang terjadi adalah hanya karena perkara sederhana dan pada mulanya hanya melibatkan orang per orang, kemudian membesar dan meluas menjadi konflik kolektif.

Berikut pemaparan sejumlah informan yang menceritakan awal mula terjadinya konflik:

Dulu kalo tidak salah tahun 80-an, wilayah sukaria dan sekitarnya belum dihuni, masih rawa-rawa. Kalo Pampang ini kampung yang dari dulu sudah ada. Jadi, di sini itu orang asli Makassar. Nanti itu ada pindahan dari Sentral, akhirnya mereka menetap di situ (Sukaria). Dulu namanya bukan Sukaria, tapi Kampung Baru. Anak-anak di sini merasa curiga, utamanya soal pendapatan. Itu orang-orang baru kayaknya memang begitu, tiba-tiba na ambil lahan kerjanya orang disini. Ya, itumi karena persoalan sumber pendapatan toh kayak lahan parkir, akhirnya tawuran mi.. Seringkali anak-anak Pampang masuk menyerang ke sana (Sukaria) (Acox, 42 Tahun).

Kalo bicara soal sejarah, pasti panjang yang mau dibahas ini dek. Ceritanya sih dulu, orang-orang dulu cerita kalo Sukaria itu kampung baru. Paling pertama itu kampung Pampang. Mereka semua pendatang. Sudah pendatang ndak tau diri poeng (Herman, 38 Tahun).

Baru-barupi itu alasannya orang konflik dengan anak-anak Sukaria karena hal-hal lain. Kayak misalkan baku ganggu, tersinggung, atau soal cewek. Tapi kalo menurut sejarah ya itu, karena mereka tidak tau dirinya pendatang baru mau tong sok-sok menguasai lahan parkir ini, lahan parkir itu (Samson, 55 Tahun).

Sementara itu, penuturan dari salah satu warga yang menjadi informan di Sukaria memaparkan terkait hal tersebut:

Hmmm... Kalo tidak salah tahun 2000-an mulai itu perang-perang anak-anak di sini sama anak-anak di sebelah. Kita itu di sini kodong kan orang baru, jadi sering itu anak Pampang datang menggertak, tapi lama-lama anak-anak di sini merasa nda terima lagi, sama-sama jiki orang Suku Makassar, biarpun orang-orang di Pampang itu asli Makassar di sini. Akhirnya anak-anak di sini melawan. Kalo 
malammi itu semua anak-anak bawa parangnya keliling jaga-jaga (Sumanto, 60 Tahun).

Pernyataan-pernyataan di atas menunjukkan bahwa pada mulanya konflik terbangun karena sebagian warga Pampang merasa terusik dengan kedatangan pendatang dari daerah lain yang bermukim di wilayah Sukaria. Ketidaknyamanan tersebut dikarenakan warga Pampang merasa orang-orang yang baru datang tersebut tidak sadar akan dirinya sebagai pendatang dan dengan seenaknya mengambil lahan kerja orang-orang Pampang, terutama lahan parkir. Oleh karena itu, sudah menjadi kesan yang terbangun sejak awal bahwa warga Pampang dalam memandang warga Sukaria sebagai 'perampas' hak milik warga Pampang.

Paling sedikit ada tiga aspek yang menjadi pemicu kekerasan kolektif yang terjadi antara kelompok Pampang dan kelompok Sukaria, yakni perebutan lahan parkir, koordinasi massa di antara kedua kelompok yang sedang bertikai, terciptanya kekerasan budaya, dan terjadinya kesenjangan nilai.

Konflik perebutan lahan parkir dapat dianggap sebagai bentuk kekerasan yang sifatnya defensif antara kelompok Sukaria dan Pampang karena kedua kelompok masing-masing berusaha untuk mempertahankan apa yang mereka anggap sebagai milik mereka. Pada kenyataannya, ketika ada sebuah lahan parkir di daerah yang beririsan dengan kedua wilayah tersebut, yang mana juru parkirnya adalah orang Sukaria, ini akan membuat warga Pampang geram dan marah. Hal inilah yang kemudian memicu pertikaian di antara kedua kelompok ini. Konflik perebutan lahan parkir merupakan bentuk awal kekerasan antara kedua kelompok ini yang lebih disebabkan karena kesenjangan ekonomi akibat keterbatasan akses pekerjaan lain. Hal ini dapat kita lihat dari pemaparan informan di bawah ini:

Awalnya perang kelompok anak-anak di sini (Pampang) dengan Sukaria itu masalah saling rebut lahan parkir. Kan lahan parkir juga jadi sumber mata pencahariaannya mereka toh, jadi tawuran mi karena mereka pikir itu lahan parkir mereka yang miliki (Acox, 42 Tahun).

Danger (21 tahun) yang tinggal di Sukaria menuturkan, bahwa 'Kayak tong dia saja yang punya itu tempat, padahal kita ini lebih dekat dari itu tempat'. Dua kutipan di atas menunjukkan bahwa masing-masing kubu (Pampang dan Sukaria) saling mengklaim dan merasa memiliki lahan parkir yang ada di sejumlah tempat tertentu, sehingga ketika ada di antara kedua kubu tersebut 
yang menguasai lahan parkir tertentu, maka akan memicu kejengkelan dan memantik perkelahian di antara mereka. Hal ini dapat dipahami mengingat letak dan jarak antara kedua wilayah Pampang dan Sukaria relatif tidak berjauhan dan memungkinkan terjadinya irisan lahan yang menjadi sumber mata pencaharian mereka, sekaligus sebagai sumber konflik.

Konflik perebutan lahan parkir ini telah membentuk orang-orang kuat lokal (jagoan, preman) di kedua kelompok yang bertikai. Orang kuat lokal (seperti orang jagi, preman atau orang berpengaruh lainnya) ini memiliki kemampuan memobilisasi massa yang kemudian dikuatkan dan difasilitasi keberadaannya oleh kelas perantara, seperti para kapital dan aparat birokrasi. Terbentuknya orang kuat lokal diekspresikan oleh Acox dan Jack di bawah ini.

Begituji memang pertama, kalo sudah merasami jago, banyakmi yang akhirnya mau dikuasai. Setelah merasa banyak yang malla' (takut) dan dianggapmi sebagai preman, na gunakanmi itu sebagai modalnya untuk bisa dapat kerjaan lain. Ndak tau juga kenapa disini anak-anak, kalo ada orang yang jago begitu dan diakui, pasti mereka mau tong kayak begitu. Itumi yang bikin banyak pengikutnya preman-preman. Selain juga karena mungkin mereka takut to kalo ada na maui itu preman $k a$ (Acox, 42 tahun).

Kalo di sini ada memang pelindungnya anak-anak, misalnya to ada anak-anak ditangkap karena berkelahi atau perang-perang cepatji itu bebas ... ini orang juga kaya di sini asal kasus berkelahiji pasti anak-anak ke sana minta bantuannya ... yang penting bukan dua hal, mencuri sama narkoba. Kalo itumi dua, angkat tanganmi itu, nda bisa miki nabantu (Jack, 27 tahun).

Faktanya, proses pembentukan orang-orang kuat lokal berupa preman-preman yang ditakuti dan disegani adalah setelah mereka melewati masa-masa tawuran berdarah. Orang-orang kuat lokal ini awalnya dikenal sebagai orang yang berwatak keras dan seiring berlangsungnya tawuran justru makin menguatkan eksistensinya. Orang kuat lokal tersebut masing-masing dikenal sebagai pelindung wilayah kelompok. Proses pembentukan orang kuat lokal ini juga seringkali 'difasilitasi' oleh kekuatan-kekuatan dan proses-proses politik yang lebih besar. Pada titik inilah peranan kelas perantara (intermediary class) yang pada umumnya merupakan suatu kelompok yang terdiri dari kelas kapitalis kecil, pejabat negara lokal yang memainkan peranan melalui pemburuan rente dan black economy (pendapatan gelap) yang diambil dari sumber-sumber negara memiliki peranan penting, seperti yang dikemukakan oleh Danger berikut ini: 
Eee biasa itu anak-anak di sini dipanggilki kalo misalkan ada sengketa tanah. Di situ tommi juga dapat uang anak-anak to. Kayak disewa begitu ee ... Ada juga biasa juga kalo misalnya demo mahasiswa, kayak kemarin di gubernuran kita dipanggil untuk serangki mahasiswa.' (Danger, 21 tahun).

Terciptanya kekerasan budaya yang terdiri dari sumber struktural dan sumber kultural. Sumber struktural berasal dari kelas perantara, yaitu peran kapital dan aparat birokrasi yang secara tidak langsung memapankan kekerasan kolektif yang terjadi. Keberadaan preman-preman, baik dari kubu Pampang maupun Sukaria telah dimanfaatkan oleh kelas perantara, entah itu pengusaha setempat, maupun pemerintah. Hal inilah yang melahirkan sumber struktural bagi kekerasan budaya antara warga Sukaria maupun warga Pampang. Sementara itu, sumber kultural berasal dari penyalahartian nilai budaya siri' dan pacce yang dilakukan oleh preman sebagai upaya pembenaran terjadinya kekerasan demi menjaga keberlangsungan status ke-premanan-nya.

Sejalan dengan hal tersebut, Galtung (1999:11) menegaskan bahwa ketika berbicara tentang kekerasan, maka pembicaraan yang dimaksud adalah penggunaan kekerasan dalam masyarakat dan legitimasi terhadap penggunaan kekerasan itu. Berikut pemaparan informan mengenai hal ini:

Iya, saya yakin itu. Saya dulu sering dikasih jatah (preman) dari wisma di depan sebanyak 300 ribu per bulan karena kita dulu yang pegang rahasianya itu tempat. Kita taumi itu tempat to tempat apa (wisma plus). Ada juga di sini aparat yang suka beli narkoba blah ... jadi susah anak-anak di sini karena orang-orang berpendidikan ji sendiri yang pelihara begitu-begituan (kejahatan)(Acox, 42 tahun).

Pernah itu ada kasus orang berkelahi gara-gara na bilang menyangkut siri'mi bede'... Anak-anaka semua disini ikut mami, ka emosimi warga pas dengar begituan. Sering juga itu ada kasus cewek-cewek disini kalo lewat di daerahnya mereka (Pampang) atau melintas di dekat situ diganggui sama pemuda-pemuda disana. Ndak pernahji iya diapa-apakan langsung (secara fisik), tapi merasa tommeki itu dipermalukan kalo dikasih begitu anak gadista ee. Siri' ri pakasiri' namanya dek ... kalo sudah begitu, tunggu-tunggumi itu kita serang (lempari batu) mereka (Anna, 40 tahun).

Itu kalo adami kasus begitu, biasanya orang yang rewa disini yang pergi pa'ngara (menantang) anak-anak di sana, sambil siapkan orang-orang untuk jaga-jaga (Sumanto, 60 tahun). 
Ini menunjukkan bahwa nilai siri' dan pacce yang dipahami oleh warga Pampang dan Sukaria kerap mereka identikkan dengan kekerasan, meskipun sesungguhnya tidaklah demikian. Nilai siri' dan pacce dalam budaya Makassar sangat erat kaitannya dengan harga diri dan martabat yang seharusnya dijaga oleh setiap anggota masyarakat. Akan tetapi, faktanya warga Pampang dan Sukaria yang sering terlibat kekerasan kolektif telah menjadikan nilai budaya siri' dan pacce ini alasan dari sejumlah tindakan kekerasan yang mereka lakukan.

Terjadinya deprivasi relatif nilai budaya siri' dan pacce, yaitu kesenjangan yang terjadi antara ekspektasi nilai dan kapabilitas nilai. Ekspektasi nilai dapat dilihat pada pandangan kelompok Pampang dan kelompok Sukaria yang mengunggulkan nilai budaya siri' dan pacce sebagai warisan nenek moyang, sedangkan kapabilitas nilai dapat dilihat pada para anggota masyarakat, termasuk preman yang menjadikan budaya siri' dan pacce sebagai logika pembenaran perilaku kekerasan mereka. Selain itu, hal ini juga digunakan sebagai strategi dalam memobilisasi massa untuk tujuan kekerasan-kekerasan kolektif yang lain, sebagaimana dikemukakan dalam kutipan-kutipan berikut ini.

Pokoknya siri'mi itu kalo menyangkut harga dirita. Apapun itu, asalkan menyangkut pelecehan dan penghinaan kita anggap sebagai pelanggaran terhadap nilai budaya siri' na pace yang kami anut. Kalo itumi yang mereka lakukan, pasti bakalan kita ndak terima dan harus dibalas secepatnya (Herman, 38 tahun).

Nilai budaya siri' na pacce yang kita yakini itu persoalan martabat dan kehormatan. Apa-apa saja yang berhubungan dengan itu berarti siri' na pacce, contohnya kalo dilecehkan anak gadista atau digangguiki duluan padahal kita tidak apa-apaiki (Sumanto, 60 tahun).

Biasa itu toh dikompor-kompori anak-anak bilang menyangkut siri' mi ini dongo (bodoh), makanya haruski bela harga dirita semua dengan cara itumi, pergi serang pihak lain. Makanya susah memang karena orang ndak tau apa itu siri' tapi jadikan siri' sebagai alasan. Kan aneh toh. Tapi mau tong ji mereka (remaja) semua ikut-ikut (Usop, 43 tahun).

Kutipan-kutipan ini menunjukkan bahwa ada semacam ketidakpahaman yang berbuah kekeliruan mengartikan nilai siri' dan pacce oleh sebagian besar warga Pampang dan Sukaria dalam proses berkehidupan sosial, terutama ketika 
menyangkut hal-hal yang sensitif di masyarakat. Hal inilah yang akhirnya memicu perseteruan panjang dan menghasilkan kekerasan kolektif di kedua wilayah yang sudah memiliki 'bara' dendam sejarah yang dapat memanas pada momen-momen tertentu.

\subsection{Pola-Pola Kekerasan}

Pola dapat diartikan sebagai bentuk atau model yang digunakan untuk membuat atau menghasilkan sesuatu. Jika disederhanakan, pola bisa berarti karakter atau ciri khas yang muncul dan terjadi di suatu daerah. Setiap daerah dipercaya memiliki karakter dan ciri khas kekerasannya masing-masing, sehingga bentuk penanganannya pun bisa jadi akan berbeda-beda pula. Mencermati pola-pola kekerasan yang terjadi di suatu daerah sangat penting, mengingat bahwa pola-pola kekerasan tersebut dapat dijadikan sebagai acuan dalam menyusun kerangka resolusi yang tepat dan menguntungkan bagi banyak pihak.

Pola-pola kekerasan kolektif yang secara kontinyu terjadi di Kota Makassar, khususnya di wilayah Pampang dan Sukaria menunjukkan setidaknya ada dua jenis pola kekerasan yang mengemuka, yaitu: konflik perkotaan dan kekerasan rutin.

Konflik perkotaan ini merupakan hasil dari jenis konflik yang terjadi pada ruang-ruang kota dengan akumulasi modal menjadi pengaruh besar terhadap terjadinya konflik. Konflik ini menyumbang sebanyak 332 insiden atau 8,3\% dari total keseluruhan konflik dan kekerasan di Indonesia (Tohari dkk. 2011:34). Adapun bentuknya berupa konflik hubungan industrial, dan perebutan ruang ekonomi di perkotaan, jasa keamanan swasta dan penggusuran pedagang kaki lima.

Dalam konteks Pampang dan Sukaria, perebutan lahan parkir menjadi varian dominan dalam konflik perkotaan ini. Beberapa petikan wawancara pada bagian atas tulisan ini juga menjelaskan perebutan lahan parkir menjadi salah satu motif mengapa perkelahian antarkelompok Pampang dan Sukaria terjadi. Pernyataan Burhan berikut ini akan semakin mempertegas konflik yang terjadi akibat perebutan lahan parkir.

Iye. Semua orang disini tau kalo penyebab awalnya itu kita berkonflik sama anak-anak di sebelah karena memang baku rebut siapa yang kuasai lahan parkir. Karena ini soal perut, pastimi 
bakalan kita bela mati-matian. Masalahnya sekarang susah orang dapat kerja (Burhan, 25 tahun).

Ini menunjukkan bahwa konflik perkotaan yang terjadi cenderung bersumber dari perebutan ruang ekonomi. Hal tersebut dikarenakan terbatasnya akses terhadap lahan pekerjaan oleh warga karena keterampilan yang dimiliki dan juga karena kompetisi yang begitu ketat. Pada kenyataannya, menjadi suatu fakta bahwa lahan kerja yang ada tidak berbanding lurus dengan jumlah orang yang ingin mengakses lahan pekerjaan tersebut.

Sepanjang tahun 2008-2010 telah terjadi 2.498 insiden kekerasan rutin atau sekitar 62,1\% dari seluruh jumlah konflik dan kekerasan di Indonesia (Tohari dkk. 2011:13). Ini menunjukkan bahwa kekerasan rutin menempati jumlah terbanyak bila dibandingkan dengan jenis kekerasan lainnya, seperti konflik antaraparat Negara dan konflik berlatarbelakang agama. Hal ini dikarenakan sifatnya yang begitu kompleks dan kekerasan seperti tawuran, penghakiman massa dan pengeroyokan merupakan bentuk dari kekerasan rutin.

Secara umum, terdapat tiga kategori kekerasan rutin di Kota Makassar, yakni: kekerasan massif, kekerasan kolektif, dan kekerasan defensif. Kekerasan massif merupakan kekerasan yang secara serentak dilakukan oleh orang banyak dengan tanpa melihat secara ketat tentang latar belakangnya. Bahar \& Sujibto (2013:26-28) mencontohkan kasus Black September yang terjadi di Makassar tahun 1997 dengan melibatkan warga Pribumi dan etnis Tionghoa sebagai contoh kerusuhan massif. Meskipun pada awalnya bermotif agama dan etnis, hal ini kemudian mengarah ke hal yang lebih kompleks. Dari pengakuan sejumlah anggota masyarakat, penyebab Black September tidak hanya melulu karena persoalan penolakan terhadap etnis Tionghoa, tapi kemudian juga merambah kepada persoalan agama dan kecemburuan ekonomi.

Menurut Bahar \& Sujibto (2013:28), kekerasan kolektif bermunculan di Kota Makassar utamanya setelah tragedi Black September. Kekerasan kolektif di Kota Makassar dapat dilihat melalui pendekatan Gustave Le Bon (2001) yang mengistilahkan kekerasan dengan crowds. Le Bon (2001:4) mengemukakan bahwa kekerasan kolektif berkaitan dengan irasionalitas, emosionalitas dan peniruan individu yang lepas pembatasan sosial suatu organisasi sosial. Dalam crowds, individu-individu saling meniru, sehingga memperbesar emosional yang ada dan menimbulkan kekerasan kolektif.

Kekerasan defensif merupakan bentuk kemarahan sosial yang didasarkan pada ketidakadilan sosial. Bentuk-bentuk daripada kekerasan defensif mengemuka 
pada pemberontakan oleh masyarakat sipil yang kemudian mengarah pada kerusuhan dengan intensitas yang lebih tinggi dan cenderung agresif.

Dalam konteks konflik antara warga Pampang dan sukaria, pola kekerasan ini dapat dilihat pada beberapa peristiwa yang pada awalnya hanya melibatkan orang perorang saja (masalah personal), namun kemudian meluas dan menciptakan varian dari kekerasan rutin. Masalah personal biasanya menyangkut ejekan atau gangguan dari seorang warga yang kemudian diteruskan menjadi persoalan kolektif, seperti yang dikemukakan oleh Jack, Adnan, Burhan dan Danger berikut ini:

Jadi dulu itu pernah ada kejadian, ada anak cewek yang diganggui waktu pergi shalat tarwih di Mesjid 45. Melaporki itu anak cewek ke kita karena kebetulan ceweknya temanta to. Sudahmi, langsung kita pergi datangi itu orang yang ternyata memang orang Pampang. Langsungki dikasih bagiannya, dikeroyok sama anak-anak. Besoknya dia pergi lapor temannya di Pampang. Berkelahi mi sedeng orang sudahnya itu (Jack, 27 tahun).

Ada juga pernah kejadian karena baku ejek-ejekji pas berpapasan, ih langsungmi sede' baku panggil teman, akhirnya berkelahimi sedeng orang. Sampe satu minggu lebih itu orang baku lempar di jembatan (Adnan, 33 tahun).

Pernah juga karena dikira dipa'ngarai waktu lewatki di depan sini naik motor baru dia gas-gas kencang motornya. Malamnya pergi dicari itu orang karena kita tauji dia tukang parkir di sana. Langsung mentong dikasih bagiannya di tempat. Nassami ndak melawan, ka dibanyaki. Kalo sudah dipukul begitu, yakin meki besok baku picca mi sede' lagi orang. Makanya kalo sudah ada kejadian begitu, pastimi siap-siap anak-anak (Burhan, 25 tahun).

Yang barusan itu terjadi waktu anak-anak baku picca di samping UMI. Baku liat jeki saja, na silassungngang (berkelahi). Itu ada anak Sukaria 13 sampe natinggalkan motornya karena ndak sempatmi na ambil. Kalo dia ambil, pasti mati di tempat itu anak karena ada yang bawa badik (Danger, 21 tahun).

Dari pernyataan beberapa informan di atas bisa kita simpulkan bahwa kekerasan yang terjadi antara Pampang dan Sukaria tidak selalu karena persoalan yang jelas dan diketahui akar masalahnya oleh setiap orang yang terlibat. Pada beberapa peristiwa, kekerasan kolektif yang terjadi cenderung dilakukan secara spontan dan ikut-ikutan. Alih-alih karena persoalan 
solidaritas kelompok, anggota yang terlibat justru melakukannya dengan tanpa memikirkan konsekuensi jangka panjang yang akan terjadi pada dirinya.

\section{Kekerasan dan Maskulinitas}

Menurut Reeser (dalam Merdeka 2013:3), maskulinitas adalah konsep-konsep gender tentang perilaku yang dibangun secara sosial dan pada umumnya terkait dengan laki-laki dimana nilai maskulinitas tidak hanya dipengaruhi oleh pergantian budaya yang ada sekitarnya, tapi juga berubah setiap generasi. Maskulinitas memiliki keterkaitan erat dengan patriarki, sementara patriarki biasanya diidentikkan dengan 'laki-laki.' Masyarakat patriarki adalah masyarakat yang hingga taraf tertentu mendukung adanya hak-hak istimewa laki-laki dengan karakteristik aksi dan gagasan yang berbau dominasi laki-laki, diidentifikasikan dengan laki-laki, terpusat pada laki-laki dan keinginan kuat untuk mengendalikan segalanya.

Darwin (1999:3) mendefinisikan bahwa maskulinitas adalah suatu stereotype tentang laki-laki yang dapat dipertentangkan dengan dengan feminitas sebagai sebagai stereotype perempuan. Dengan demikian, jika maskulinitas dikatakan sebagai bentuk stereotype, berarti suatu bentuk konstruksi sosial tentang bagaimana seharusnya laki-laki berperilaku, sehingga seorang laki-laki dapat dikatakan sebagai laki-laki. Stereotype ini membedakan antara perempuan dan laki-laki, misalnya laki-laki dicirikan agresif, terbuka, kasar dan rasional sedangkan perempuan dicirikan dengan tertutup, halus, afektif dan emosional. Stereotype ini jugalah yang pada gilirannya menciptakan hubungan yang bias antara laki-laki dan perempuan, di mana hegemoni laki-laki atas perempuan dianggap sesuatu yang kodrati. Penciptaan stereotip ini telah membuat pemahaman kedua kelompok bahwa laki-laki yang tidak memenuhi stereotip tersebut akan dengan mudah disamakan dengan perempuan (atau waria).

Dalam konteks kekerasan kolektif antara kelompok Pampang dan kelompok Sukaria di Kota Makassar, terdapat suatu fakta menarik, yaitu semua warga yang terlibat dalam kekerasan kolektif tersebut adalah laki-laki. Berikut pemaparan dari hasil wawancara infroman:

Cuman anak laki-laki ji yang diizinkan pergi baku lempar-lempar. Kalo perempuan disini paling ibu-ibunya yang bantu ambilkan batu. Itu kalo baku lempar. Tapi kalo pergi berkelahi langsung, ndak ada pasti anak-anak cewek pergi begitu-begituan (Acox, 42 tahun). 
Dilarang anak-anak cewek pergi berkelahi atau tawuran. Laki-laki ji yang begitu (Sumanto, 60 Tahun).

Ini menunjukkan bahwa perkelahian identik dengan laki-laki. Fakta di atas juga turut serta memperlihatkan eratnya pengaruh maskulinitas terhadap kekerasan kolektif yang terjadi di kedua wilayah ini, bahwa laki-laki cenderung diwajarkan ketika berhadapan dengan perilaku kekerasan atau peristiwa perkelahian sebagai bentuk representasi kelaki-lakiannya.

Konstruksi maskulinitas dalam penelitian ini dimaksudkan untuk menggambarkan pemahaman 'laki-laki' warga Sukaria dan warga Pampang dalam menafsirkan makna siri' na pacce dan kaitannya dengan kekerasan kolektif. Berikut penuturan Acox:

Ndak tau kenapa kita ini laki-laki selalu dianggap sebagai pelindung kehormatan dan penjaga budaya yang ada, termasuk mi siri' na pacce itu tadi. Makanya haruski selalu siap dengan keadaan yang ada, terutama kalo itu menyangkut perempuan. Banyakmi kasus perempuan sering jadi sumber tawuran disini, karena mereka merasa diganggui atau dilecehkan sama orang lain. Kita tommi ini laki-laki yang punya fisik lebih kuat dari perempuan, makanya kita tommi' yang harus ada di depan kalo ada masalah yang menyangkut siri' na pacce'ta (Acox, 42 tahun).

Ini menunjukkan bahwa ada suatu pemahaman dari sebagian warga Pampang, maupun Sukaria terkait budaya siri' dan pacce yang telah membentuk konstruksi sosial terkait bagaimana seharusnya seorang laki-laki menjadi lakilaki. Siri' yang secara umum dipahami sebagai harga diri dan pacce sebagai nilai untuk saling membantu telah terpahami bahwa laki-laki yang seharusnya menjadi garda terdepan dalam menjaga dan merawat nilai-nilai ini. Oleh karena itu, jalan kekerasan menjadi satu dari sekian jalan yang harus diambil jika suatu masalah berhubungan dengan siri'. Akan tetapi, kekerasan justru menjadi jalan yang paling sering ditempuh dalam kaitannya dengan siri' tersebut. Berikut penuturan infroman:

Anak-anak itu rata-rata berpikir kalo berhubunganmi dengan siri', maka apapun itu bakalan dilakukan. Kalo ada salah satu anak-anak dipukul na melapor pasti anak-anak itu langsung menyerang ... tinggiki budaya saling membantunya anak-anak di sini, kalo ada dipukul baru sama anak-anak bukan dari daerah sini pasti cepatki semua bergerak itu ... kalo ada yang tidak bergerak dibilangi bura'ne apako anjo kau ... biasa dibilangi bencong kau. Ada dulu kasus, sekitar awal-awal tahun 2015 atau akhir-akhir tahun 2014, pas 
dipukulki pemuda disini sama warga disana, langsungki melapor disini, pas besoknya perang mi orang (Adnan, 33 tahun).

Penjelasan Adnan di atas menggambarkan sisi maskulinitas kelompok Sukaria yang dikaitkan dengan penerapan nilai siri' dan pacce terkait kekerasan. Lakilaki kelompok Sukaria memahami bahwa jika salah satu anggota dari kelompok Sukaria mengalami perlakuan yang tidak wajar dari kelompok lain, maka menjadi kewajiban bagi anggota kelompok untuk membelanya dan membalas perlakuan tersebut dengan jalan menyerang kelompok lain tersebut. Jika terdapat anggota dari kelompok Sukaria yang tidak setuju, maka terlontarlah ucapan-ucapan yang merendahkan kelaki-lakiannya atau cemohancemohan yang menyamakan orang yang tidak setuju tersebut dengan mental perempuan ataupun waria.

Lalu bagaimana dengan kelompok Pampang? Temuan penelitian menunjukkan bahwa karakteristik maskulinitas yang dimilikinya tidak jauh berbeda dari apa yang digambarkan oleh kelompok Sukaria. Karakteristik maskulinitas laki-laki Pampang juga bertautan erat dengan momen kekerasan kolektif yang terjadi. Penggambaran maskulinitas secara umum kedua kelompok ini dijelaskan oleh Informan Acox.

Laki-laki itu dilahirkan sebagai pemimpin, paling tidak sebagai kepala rumah tangga, pemimpin dalam rumah tangganya. Anakanak di sini terbiasa mendengar kalo laki-laki itu harus berani. Jadi, kecil diajar meki kalo ada temanmu pukulko pukul tongi karena lakilakiko itu, dari kecil diajarmiki kalo berkelahi itu bolehji kalo laki-laki, kalo saya dulu dijempolka sama bapakku kalo ada anuka na berkelahika. Nabilang bapakku, begitu memang anak laki-laki (Acox, 42 tahun).

Apa yang digambarkan oleh Acox di atas pada umumnya juga dipahami oleh informan lain bahwa memang laki-laki yang memegang peranan penting di dalam masyarakat. Sejumlah warga yang sering terlibat tawuran memahami bahwa laki-laki itu harus berani, apalagi jika berhubungan dengan siri'. Mereka juga memahami bahwa laki-laki itu adalah pelindung baik bagi keluarga, teman maupun kelompok. Penjelasan Informan di atas juga mengungkapkan bahwa di dalam lingkungan, baik itu tempat tinggal, maupun lingkungan keluarga seolah-olah secara permisif mengakui perilaku kekerasan laki-laki. Lingkungan telah mengajarkan bahwa jika laki-laki berkelahi itu adalah hal yang wajar. 
Doktrin semacam ini melekat pada anak laki-laki, baik bagi kelompok Sukaria maupun kelompok Pampang, sehingga jika ada hal-hal yang berhubungan dengan siri', ini akan sangat mudah menyulut emosi yang akhirnya menyebabkan perilaku kekerasan di masyarakat. Doktrin kebudayaan seperti ini juga disadari atau tidak telah membentuk pemahaman bagi kedua kelompok bahwa kekerasan adalah salah satu jalan untuk membuktikan kelakilakian seseorang.

Konstruksi maskulinitas sebagaimana apa yang dipaparkan di atas ditandai bahwa warga yang terlibat dalam kekerasan kolektif dominan merupakan lakilaki. Sebagaimana pula yang dikemukakan oleh Harders (2011:143) bahwa lakilaki beresiko tinggi untuk terlibat dalam berbagai macam bentuk kekerasan. Konstruksi maskulinitas telah sampai pada pemahaman bahwa kekerasan adalah jalan yang harus dilalui jika menyangkut siri' na passé. Hal ini dipengaruhi oleh pola asuh lingkungan utamanya keluarga yang melakukan pembiaran perilaku berkelahi laki-laki.

Pada sisi lain, konstruksi maskulinitas juga cenderung karena disebabkan oleh persoalan perempuan. Ada semacam kesan yang terbentuk bahwa perkelahian (kolektif) yang dilakukan oleh laki-laki menyangkut persoalan perempuan untuk membuktikan sifat kelaki-lakian (kaporeanna) mereka terhadap perempuan-perempuan yang ada di lingkungan tersebut. Seperti yang dikemukakan oleh Samson dan Usop berikut ini:

Paling sering itu anak-anak Sukaria dengan anak-anak Pampang tawuran kalo bulan puasa, di situ di Mesjid 45, sampingnya dekat sungai ... kalo bulan puasa itu banyak cewek pergi shalat, baku kumpulki semua mau cewek-cewek dari sini dengan cewek-cewek dari Pampang juga, itu tommi biasa tawuranmi karena urusan cewek. Mau nakasi liat-liat toh (Samson, 55 tahun).

Contohmi itu waktu puasa kemarin (tahun 2014), anak-anak cewek disini diganggui sama anak-anak sana, pas pulang dari tarawih na tanyaki pemuda yang lagi ngumpul-ngumpul di depan, akhirnya perangmi sede' orang (Usop, 43 tahun).

Harders (2011:143), menekankan bahwa kekerasan dapat tetap dipahami sebagai sumber identitas bagi laki-laki. Hal ini terkait dengan gagasan bahwa habitus laki-laki dibentuk melalui kompetisi yang tercipta di antara laki-laki. Kompetisi-kompetisi ini dapat dilihat perwujudannya melalui berbagai lembaga homososial, seperti militer, kelompok pemuda dan geng, penjara, sekolah anak laki-laki, olahraga dan beberapa profesi lainnya yang merupakan 
ruang simbolik bagi laki-laki untuk memainkan kompetisi ini demi identitas diri. Melalui kompetisi dalam ruang simbolik inilah maskulinitas dibentuk dan dicapai serta memberikan pengalaman bagi laki-laki.

Keberadaan kelompok Pampang maupun kelompok Sukaria telah membentuk semacam kompetisi sebagai cara untuk membuktikan kelaki-lakian para kelompok yang berkonflik. Tawuran adalah salah satu upaya kompetisi untuk menciptakan stereotype laki-laki yang tangguh dan pemberani. Jadi, sesuai dengan pandangan tersebut di atas bahwa tawuran di antara kedua kelompok ini telah berubah menjadi ajang kompetisi eksistensi.

Penelitian ini juga menunjukkan representasi maskulinitas yang dapat dilihat melalui penggunaan badik dan busur panah pada saat tawuran, adanya tattoo di tubuh serta minuman khas ballo' sebagai ritual sebelum memulainya tawuran. Badik merupakan senjata tradisional yang digunakan oleh subyek kekerasan. Dengan membawa badik, seorang subyek kekerasan merasa dirinya berada di atas angin. Hal ini pulalah yang membuat mereka lalu merasa menjadi lebih laki-laki, bernyali dan berani terhadap lawan-lawannya. Penggunaan senjata busur panah sebagai sesuatu yang mendukung maskulinitas kedua kelompok ini juga dijelaskan oleh berbagai penelitian. Merdeka (2013:3-5) mengemukakan bahwa menjadi maskulin tidak selalu berhubungan dengan physical apprearance atau yang berhubungan dengan aktifitas fisik, kepemilikan senjata baik senjata api maupun senjata tradisional dapat menunjukkan dan mendukung maskulinitas seorang laki-laki. Dengan memiliki senjata, akan membuat identitas seseorang menjadi lebih maskulin dan kuat, meskipun juga tidak selalu begitu. Pierre Bourdieu (2010:14) dalam analisisnya menggambarkan aspek maskulinitas salah satunya adalah dengan senapan (senjata api). Dalam konteks Makassar, senjata tradisional yang dimaksudkan adalah badik, sebagaimana yang diungkapkan oleh Danger berikut ini:

Kalo perang orang, biasaka bawa badik, biasa tong ndak saya bawa. Biasa juga saya lupa bawa, karena saya simpan di tempat yang sembunyi di dalam rumahku. Saya kalo pegangma badik na orang tawuran, pasti selaluka mau paling depan. Ndak adami takutku saya rasa. Nassami karena orang juga pasti malla' majuika to (Danger, 21 tahun).

Selain badik, senjata tajam busur juga terkadang digunakan di kedua kelompok yang sedang berkonflik. 
Kadang-kadang $j i$ ada busur saya bawa. Tidak selalu, soalnya panaski blah kalo dibawa-bawa. Selaluki merasa mau bagimanabagaimana sama orang lain. Kalo busur itu ndak dibawa-bawa. Busur biasanya kita pakai kalo perangpi. Badikji yang biasa kalo mau dibawa-bawa iyya (Jack, 27 tahun).

Ini menunjukkan bahwa penggunaan badik lebih umum digunakan ketimbang penggunaan busur. Selain itu, penggunaan badik juga biasanya dilakukan ketika warga dari wilayah tertentu sedang melakukan 'patroli' di sekitaran wilayah mereka. Itu artinya membawa badik lebih banyak dikarenakan ketika mereka sedang berjaga-jaga, baik karena kondisinya sedang 'tegang' atau karena sedang ada kejadian seorang teman mereka dianiaya oleh kelompok lain, seperti penuturan Acox berikut ini:

Anak-anak biasa bawa badik kalo lagi jaga-jaga ji. Biasanya karena lagi panaski ini Pampang sama Sukaria. Mungkin karena tadi ada yang dipukul sama anak sana (Acox, 42 Tahun).

Namun tattoo juga merupakan representasi maskulinitas bagi kelompok Pampang maupun kelompok Sukaria, sebagai simbol keberanian. Oleh karena itu, jika ingin dianggap memiliki nyali tinggi, salah satunya adalah dengan menatto bagian tubuh, seperti yang dituturkan oleh Danger berikut ini:

Kalo mauki dibilangi berani, punya nyali tinggi, ya bertatto meki. Iya awalnya saya memang coba-coba, biasa pengaruh pergaulan, mau tongki supaya terlihat jantan...tapi lama-lama kusadariji juga kalo tatto itu harus ada maknanya, itumi kutambai terus tattoku ini, jadi tiap ada tatto kubikin ada semua artinya, ada kenangannya juga (Danger, 21 Tahun).

Herman menjelaskan bagaimana tatto awalnya identik dengan narapidana, seperti yang diungkapkannya berikut ini:

Dulu itu kita kalo matatto, lepas peki dari penjara baru mattattoki. Dulu orang matatto dalam penjaraji. Pertama itu berhubungan anakanak seni yang masuk penjara. Awalnya itu tatto sama semua, kalo satu orang tatto kapak berarti semua itu sama tattonya. Pernah kita itu tatto mawar tersembunyi semuanya, ndak boleh kelihatan, karena perkembangan banyak orang ditangkap kita tutup semua. Dulu saya itu ada delapan tahun saya tukang tattoo, jadi memang laki-laki saja yang bertatto tidak ada perempuan...tidak wajar menurut saya kalo perempuan bertatto karena tatto itu lambang kejantanan... Dulu orang tua kita tattonya semacam pengenalanji, kalo matatto ya tatto-tatto kecil dari getah jambu monyet, jadi ada 
juga budaya tatto di nenek moyang untuk tahu dimana letak besi dalam dirita semacam menggambarkan karakterta. Tapi gambaran tatto dulu itu tidak kelihatan atau tersembunyi, jadi kalo didapatmi letak dirita dikasihmi sama getah jambu monyet jadi menyatuki dengan kulit (Herman, 38 Tahun).

Danger yang mendapat julukan 'Panglima Perang' dari Sukaria hampir seluruh tubuhnya bertatto. Meskipun awalnya hanya coba-coba dan sekedar hanya ingin dikatakan rewa, namun pada perkembangannya, ia menyadari bahwa tatto yang ada pada tubuh haruslah memiliki makna yang sesuai kondisi kehidupan yang dialaminya.

Selain senjata tajam (tradisonal) dan tattoo, minuman keras (miras), yaitu ballo' juga merupakan salah satu representasi maskulinitas para preman, baik dari wilayah Pampang maupun wilayah Sukaria. Minuman yang memabukkan ini juga menjadi pemicu kekerasan kolektif antara kedua kelompok ini. Berikut penuturan beberapa informan terkait minuman ballo' ini:

Ballo ini jadi minuman perekat persatuanta. Kalo mauki dianggap bagian dari kelompok, haruski ikut minum. Kalo ndak, berarti kita menyinggung perasaan yang lain (Danger, 21 tahun).

Kalo ada anak-anak yang ndak sentuh minuman (ballo') pasti dicapki bencong. Baru begini, ndak bisami. Belumpi itu kalo berhadapan sama musuhta (Jack, 27 tahun).

Memang itu ballo' tinggi tong artinya bagi warga. Tapi ndak bisa juga dipungkiri kalo biasa minum begitu, itu tongmi kalo telermi na sembarang nabilang, biasa para-para diaji baku picca (berkelahi) (Acox, 42 tahun).

Biasa juga gara-gara sudah minum, sambarang na ganggui, na biasa ndak sadarmi toh kalo ternyata yang naganggu itu anak sebelah (Sukaria) (Burhan, 25 tahun).

Dari sejumlah penuturan informan di atas dapat kita lihat bahwa ballo' menempati posisi khusus dalam masyarakat Pampang dan Sukaria, terutama dalam kaitannya dengan maskulinitas. Laki-laki yang dianggap maskulin adalah laki-laki yang pernah meminum ballo' dan tahan lama tidak sampai mabuk berat ketika meminum minuman tersebut. Dalam konteks sejarah, minuman ballo' juga telah menjadi simbol kejantanan bagi kaum laki-laki pada suku Bugis-Makassar. Oleh karena itu, minuman khas ini sulit untuk 
dilepaskan dari budaya masyarakat terutama jika berbicara mengenai kekerasan kolektif yang terjadi antara kelompok Pampang dan Sukaria.

\section{Kesimpulan}

Maskulinitas berperan aktif dalam menciptakan kekerasan kelompok antara warga Pampang dan warga Sukaria di Kota Makassar. Kekerasan kelompok tersebut mengemuka terutama dikarenakan permisifitas masyarakat yang melakukan pembiaran terhadap perilaku kekerasan yang dilakukan oleh lakilaki. Meskipun pada awalnya kekerasan kelompok dilakuan untuk perlindungan diri, namun lama kelamaan kekerasan dilakukan untuk kompetisi dan kesenangan semata. Pada titik inilah konstruksi dan representasi maskulinitas terwujud.

Selain itu, konsepsi maskulinitas yang terpahami oleh anggota masyarakat sangat erat kaitannya dengan pola asuh di lingkungan mereka, terutama dari keluarga cenderung mengidentikkan laki-laki dengan kekerasan. Selain itu, penelitian ini juga memperoleh temuan bahwa selain motif ekonomi dan perebutan lahan kerja, posisi perempuan juga menjadi salah satu pemicu terjadinya tawuran antar kelompok di kedua wilayah ini. Laki-laki seolah ingin menunjukkan kepada perempuan di lingkungan sekitarnya bahwa mereka memiliki sifat kelaki-lakian dengan cara mempertontonkan aksi kekerasan mereka.

Representasi maskulinitas terkait kekerasan kolektif disimbolkan oleh empat hal, yaitu badik, busur panah, tattoo dan ballo. Badik merupakan senjata tradisional yang dibawa dan terkadang digunakan oleh subyek kekerasan agar membuat mereka merasa menjadi lebih berani dan bernyali. Sementara itu, busur panah merupakan senjata yang pada umumnya digunakan ketika tawuran jarak jauh berlangsung. Kepemilikan busur panah bagi subyek-subyek kekerasan secara psikologis mampu meningkatkan keberanian dalam diri mereka. Hal inilah yang membuat busur panah diasosiasikan dengan maskulinitas. Tatto' juga adalah representasi dari kejantanan bagi para subyek kekerasan. Pada umumnya, para 'panglima' di kedua kelompok ini memiliki tatto' di bagian tubuhnya. Motif awalnya adalah coba-coba sebagai pengaruh lingkungan yang menggambarkan bahwa orang yang ber-tatto' adalah orang yang rewa, ditakuti dan disegani. Selain itu, ballo' yang merupakan minuman khas tradisional juga merupakan simbol 'kejantanan' bagi laki-laki pada kedua kelompok ini. Meminum ballo' seolah-olah juga telah menjadi bagian dari ritual sebelum tawuran dimulai. 
Resolusi konflik dalam penelitian ini didasarkan pada pandangan Dharmawan (2007), pada tataran konflik antar masyarakat atau kolektifitas sosial seperti yang terjadi antara kelompok Pampang dan kelompok Sukaria. Dharmawan (2007:11-12) menawarkan dua pendekatan, yakni pertama, pendekatan berbasis resolusi konflik yang berorientasi nilai-kultural (etik, norma) melalui pemanfaatan simbol-simbol dan norma kultural sebagai pemersatu para pihak yang berkonflik. Kedua, pendekatan resolusi konflik berbasis atau berorientasi pengembangan struktur kelembagaan melalui forum komunikasi dan memberdayakan 'ruang komunikasi publik', serta membangun kesepakatan bersama berbasiskan kemitraan dan saling pengertian.

Upaya resolusi konflik yang dilakukan dalam menangani kekerasan kelompok antara warga Pampang dan warga Sukaria terdiri dari pendekatan budaya dan pendekatan kelembagaan. Sementara itu, upaya pendekatan kelembagaan dilakukan atas kesadaran masyarakat sendiri, utamanya tokoh pemuda di masing-masing kelompok dengan membentuk organisasi pecinta alam yang para anggotanya didominasi oleh remaja yang terbiasa ikut tawuran.

\section{Daftar Pustaka}

ASKI. (2013). Pemetaan Aktor-Aktor Kekerasan Kepemudaan dan Sejarah Kekerasan Kepemudaan di Jakarta, Yogyakarta dan Makassar. Jakarta: Kementerian Pemuda dan Olahraga.

Bourdieu, Pierre. (2010). Dominasi Maskulin (Terj.). Yogyakarta: Jalasutra.

Bahar, Ahmad \& Sujibto, Bernando J. (2013). Rusuh Makassar: Membaca Pola-Pola Kerusuhan Di Makassar. Jakarta: Solusi Pubhlising.

Darwin, Muhadjir. (1999). Maskulinitas: Posisi Laki-Laki dalam Masyarakat Patriarkis. Yogyakarta: Center For Population and Policy Studies, Universitas Gadjah Mada.

Dharmawan, Arya Hadi. (2007). Konflik-Sosial dan Resolusi Konflik: Analisis SosioBudaya (Dengan Fokus Perhatian Kalimantan Barat). Disampaikan pada Seminar dan Lokakarya Nasional Pengembangan Perkebunan Wilayah Perbatasan Kalimantan, 10-11 Januari, Pontianak.

Galtung, Johan. (1999). Kekerasan kultural dalam Wacana Kekerasan dalam Masyarakat Transisi, Yogyakarta: Insist Book.

Harders, Cilja. (2011). Gender Relation, Violence and Conflict Transformation. In B. Austin, M. Fischer, H.J. Giessmann (eds.). Advancing Conflict Transformation. The Berghof Handbook II. Opladen/Farmington Hills: 
Barbara Budrich Publishers, www.berghof-handbook.net, diakses tanggal 15 Agustus 2014.

Hasse, J. (2012). Anarkisme Demonstrasi Mahasiswa: Studi Kasus Pada Universitas Islam Negeri Alauddin Makassar. Program Studi Ilmu Agama \& Lintas Budaya. Sekolah Pascasarjana UGM, Yogyakarta.

Le Bon, Gustave. (2001). The Crowd: A Study of Popular Mind. Kitchener: Batoche Books.

Manji, Taufik. (2011). Studi Analisis Peran Pemerintah Kota Terhadap Perkelahian Antar Kelompok Di Kota Makassar. Skripsi, Program Studi Ilmu Pemerintahan FISIP, Universitas Hasanuddin, Makassar.

Merdeka, Pita. (2013). Senjata Api dan Maskulinitas Dalam Cerita Pendek The Man Who Was Almost A Man. Fakultas Adab dan Humaniora, Universitas Islam Negeri (UIN) Syarif Hidayatullah, Jakarta.

Santoso, Thomas. (2002). Teori-Teori Kekerasan. Surabaya: Penerbit Ghalia Indonesia.

Sardiman, A.M. (2007). Interaksi dan Motivasi Belajar Mengajar. Bandung: Rajawali Pers.

Sahab, Ali dan Muzaqqi, Fahrul. (2012). Analisis Kultural-Politik Kekerasan Mahasiswa di Kota Makassar. Universitas Airlangga, Surabaya.

Tohari, Amien; Yuda Saputra, Dany; Novrian S, Didi; Yanuardy, Dian; Taschler, Lisa; Muntaza; Swanvri; dan Soumahu, Rio. (2011). Dinamika Konflik dan Kekerasan Di Indonesia. Jakarta: Institut Titian Perdamaian. 